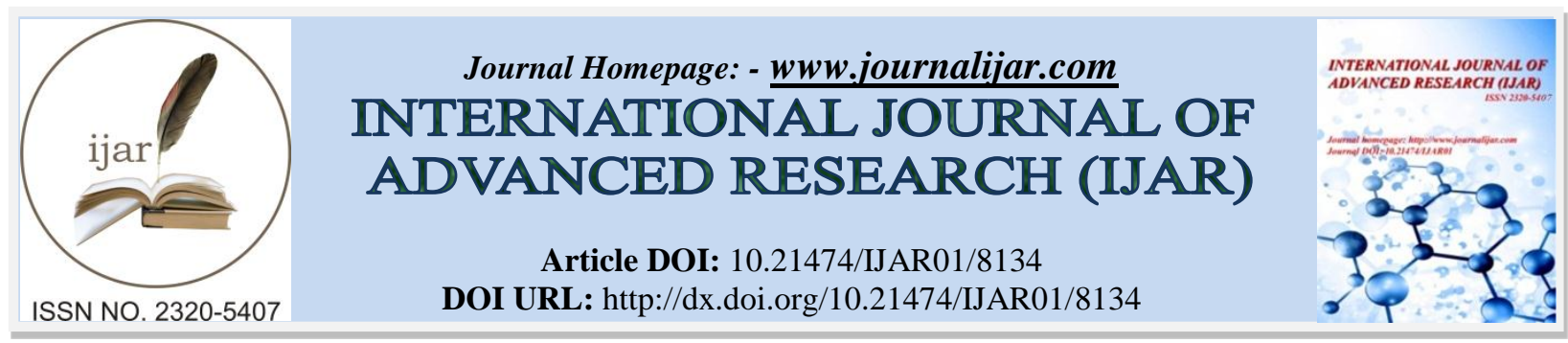

RESEARCH ARTICLE

\title{
ANALYSIS OF AUDITOR PERFORMANCE THROUGH PROFESSIONAL COMMITMENT AND WHISTLE BLOWER.
}

Fitriah karmita, Abdul Hamid Habbe and Andi Kusumawati. Accounting Department, Hasanuddin University.

\section{Manuscript Info}

Manuscript History

Received: 01 October 2018

Final Accepted: 03 November 2018

Published: December 2018

Keywords:

Organizational Culture, Ethical Orientation, Professional Commitment, Whistleblowers, Auditor Performance

\begin{abstract}
This study aims to examine and analyze the influence of organizational culture and ethical orientation on professional commitment and whistleblowers. This study also examined and analyzed the mediating effects of professional commitment and whistleblowers in the relationship of the influence of organizational culture and ethical orientation on auditor performance. This study uses a survey method with data collection techniques using a questionnaire. The research data were analyzed using the method of structural equation modeling (SEM). The sample used was 76 auditors selected based on certain criteria (purposive sampling). This study provides results that (1) organizational culture influences professional commitment; (2) organizational culture influences auditor performance through professional commitment; (3) ethical orientation influences professional commitment; (4) ethical orientation influences auditor performance through professional commitment; (5) organizational culture influences the whistleblower; (6) organizational culture influences auditor performance through a whistleblower; (7) ethical orientation does not affect the whistlebower; (8) ethical orientation does not affect the auditor's performance through a whistleblower; (9) professional commitment influences auditor performance; (10) whistleblowers influence auditor performance. The implications of this research are that this research is expected by government organizations, in this case internal government auditors, to pay more attention to increasing the auditor's professional commitment and increasing the system of openness in the organization to encourage auditors to become whistleblowers. Increasing professional commitment and becoming a whistleblower are expected to further improve auditor performance.
\end{abstract}

Copy Right, IJAR, 2018,. All rights reserved.

\section{Introduction:-}

As time goes on, accountability for the performance of a government-owned institution is very important. Every agency that manages funds that protect the lives of many people can provide accountability for its management. A fact quote from the international survey institute said that, Indonesia in 2017 was ranked 96 out of 180 surveyed countries on the Corruption Perception Index (CPI) with a score of 37 out of 100, while in 2014 was ranked 107 out of 175 surveyed countries on the Corruption Perceptions Index (CPI) with a score 34 out of 100, (Transparency

Corresponding Author:-Fitriah karmita.

Address:-Accounting Department, Hasanuddin University. 
International, 2017). The results were issued by an international non-government organization that ranked corruption with countries as a barometer of global corruption and corruption perception index. Based on this information, we can see that Indonesia has gained a position that has continued to increase over the past four years. This ranking increase is not something to be proud of. The practice of corrupt state administration will certainly have a negative impact on people's welfare and development in Indonesia.

This cannot be separated from the role of an internal auditor. Internal inspection is a critical activity and requires disclosure that may be a threat to the party being examined. An auditor's credibility and independence is at stake when examining a financial statement or the operational performance of an organization. The auditor is expected to be able to assess fairness and help by revealing the findings of the organization's good and bad for the continuity of the organization.

Kalbers and Forgatty (1995) suggest that auditor performance is an evaluation of work performed by superiors, coworkers, themselves, and direct subordinates. In measuring auditor performance, according to Larkin (1990) there are four dimensions of personality, namely: 1) Ability (ability), namely the ability of someone in completing work. This is influenced by the level of education, work experience, occupation and age. 2) Professional Commitment, namely the level of individual loyalty to the profession. 3) Motivation, which is a condition in a person who encourages the individual's desire to carry out certain activities to achieve a goal. 4) Job Satisfaction, which is the level of individual satisfaction with its position in the organization. Based on some of the above meanings, it can be concluded that auditor performance is a work that is achieved by an auditor in carrying out the tasks assigned to him based on weakness, experience, and the accuracy of time measured by considering quantity, quality, and time.

Theory of Planned Behavior states that one of its determinants, which is related to one's basic attitude, is called attitude toward the behavior (a person's attitude towards behavior). An example is a person's attitude towards intuition, towards another person, or to an object. In this case, the auditor's attitude towards the environment in which he works (office), to his supervisor or to an explanation from his client and of course on giving his opinion on the financial statements. Organizational commitment shows the existence of a power from someone in identifying their involvement in a part of the organization (Mowday, et. Al, 1992).

Aranya et al. (1981) argue that higher professional commitment must be reflected in a stronger sensitivity to problems regarding professional ethics. This also arises based on one's consideration of what he thinks is good and right. A strong work professional commitment is usually found in someone who has a long working period, those who have achieved success with the organization concerned, and they have a high professional commitment to the work and the work organization as a logical consequence. Commitment to work professionals cannot be separated from the form of the relationship between the employee and the work or profession where the employee works. Commitment is defined by Suharyanto and Tata Iryanto (1996: 235) as an agreement to do something. Although there is a word "agreement" commitment tends to have the meaning of making an agreement with yourself. Although there is a word "agreement" commitment tends to have the meaning of making an agreement with yourself. If someone in making a decision is accompanied by professional commitment, then of course he will strive and strive to live the decision as well as possible, be serious and responsible (Febrianty, 2012).

A person's commitment will be built up over time and the organizational culture that shelves it. Every organization has a characteristic that distinguishes it from other organizations, this characteristic becomes the identity of the organization. This characteristic is called organizational culture. Organizational culture refers to a unique relationship of norms, values, beliefs, and ways of behaving that characterize how groups or individuals solve things. Organizational culture contains values that must be understood, imbued, practiced together by all individuals or groups involved in them. Culture relates to how organizations build commitment to realize a vision, win customers or stakeholders, win competition, and build organizational strength. According to Huntington, culture determines the progress of every organization, no matter what type of organization it is. (Zebua, 2009)

Professional ethics research (accountants) in Indonesia has been carried out. However, this study is still limited to the cognitive aspects of accountants (specifically the relation to ethical decision making). The American Heritage Directory states ethics as a rule or standard that determines the behavior of members of a profession. Agus (2014) states that to understand ethics needs to be distinguished from morality. Morality is a system of values about how someone must live as a human. This value system is contained in the teachings; morality gives humans rules or 
concrete instructions on how to live, how to act in this life. As a good human being and how to avoid bad behavior. On the one hand ethics speak of moral values and norms that determine human behavior in his life.

Weak integrity is one factor that drives corruption by regional heads. In addition to of course the weaknesses in the supervision system in the process of procurement of goods and services in the area. This also made many regional heads not deterred even though many regional heads were arrested by the KPK. Structural strengthening of the Government Internal Supervisory Apparatus (APIP) is increasingly urgent. Currently APIP is only a paper tiger. It is very difficult for auditors and employees of the Inspectorate who are appointed and dismissed by regional heads to supervise their superiors until sanctions are imposed. To that end, the KPK encourages improvements in regulations such as the Government's Internal Control System Bill. This has become a necessity to prevent regional head corruption from continuing.

Regulation of the State Minister for Administrative Reform Number PER / 05 / M.PAN / 03/2008 contains general standards that must be adhered to by an internal auditor, that is, the auditor must be independent and objective in matters relating to the audit, must have expertise means that an auditor has knowledge, skills, and other competencies needed to carry out their responsibilities. An auditor must also have professional precision that is where an auditor must use due professional care carefully and carefully or often referred to professional and careful proficiency in each assignment and compliance with the code of ethics.

Some issues say that the regional inspectorate does not work according to its role, because it is ane level with the Regional Work Unit (SKPD) and other agencies, and the position of regional inspectorates under the Regional Head has made its independence doubtful. This is because, when supervision is under the responsibility of the Regional Head, supervision of the performance of the regional government will never be considered objective. The Inspectorate in carrying out its duties is expected to maintain an independent and objective judgment. Independent means having a neutral and unbiased attitude and avoiding conflicts of interest both in planning, implementing and reporting on the work done.

Regulations concerning whistleblowing in Indonesia have been regulated in Law Number 13 of 2006 concerning Witness and Victim Protection and Supreme Court Circular Letter Number 4 of 2011 concerning Treatment of whistleblowers and Acting Witnesses who Cooperate (Witness and Victim Protection Agency , 2011). However, the application of these rules is not optimal without a good whistleblowing system. Septiyanti (2013) explains that an effective, transparent and responsible whistleblowing system is expected to overcome employee reluctance to report suspected violations and is expected to increase employee participation in reporting suspected violations.

Mulyadi (2015) conducted a normative study, reviewing legislation concerning legal protection against whistleblowers and justice collaborators in criminal acts of corruption. This research shows that inadequate legal protection received by the Whistleblower or Justice Collaborator in the Corruption Act because of legal protection to the Justice Collaborator and Whistleblower is carried out when carrying out community participation to help prevent and eradicate corruption in addition to the concept of legal policy crimes against the Whistleblower and Justice Collaborator in future corruption are oriented to the dimensions of the concept of non-reasoning approaches which are restorative justice and legal protection approaches to those who work together then the imposition of criminal law with special conditional criminality, special remission and accelerated conditional release and several the protection model of the Whistleblower and Justice Collaborator.

In carrying out the role of the audit, the auditor is responsible for planning and carrying out the audit in order to obtain sufficient confidence whether the financial statements are free of material misstatements. With the support of competencies and audit techniques as well as other competencies from the formal and informal levels of education and experience in audit practice, the auditor must be able to collect and evaluate the evidence used to support the given agreement.

The internal auditors who are in the spotlight this time are internal government auditors. The Government Internal Auditor, better known as the Government Functional Supervision Apparatus (APFP) carried out by the Financial and Development Supervisory Agency (BPKP), Department of Inspectorate General / LPND, and Regional Supervisory Agency. Until now, not all APIP (Government Internal Supervisory Apparatus) have uniform standards, therefore this study uses the State Apparatus Empowerment Ministerial Regulation Number: PER / 05 / M.PAN / 03/2008 dated March 31, 2008 concerning Apparatus Audit Standards Government Internal Supervision. In the 
ministerial regulation the audit standard is the government internal control apparatus, covering standards related to organizational characteristics and individuals conducting audit activities. In the General Standards on expertise, broadly stated that the expertise of the examiner must have an educational background, technical competence, position certification and education and training.

The educational background of an APIP has a minimum level of formal education (S1) or equivalent. APIP must have certain criteria in planning an audit, identify the auditor's professional needs and to develop audit techniques and methodologies to fit the situation and conditions faced by the unit served by APIP. An APIP is required to take position certification and continuing training education, among others, as follows: Examiners must have certification of functional auditor positions (JFA) and participate in continuing professional education and training (continuing professional education). The examiner is obliged to take education and training on the auditor's functional position in accordance with his level.

Other cities and districts that stole the attention were Maros Regency, Gowa Regency and Takalar Regency. The Sindo.news.com website writes that these three districts each have different values. Maros Regency obtained a value of 37.29 with the title of C. Gowa Regency obtained a value of 61.16 with the predicate B, and Takalar District obtained a value of 55.28 with the predicate of CC. These three areas are the closest areas of the city of Makassar, known as the Mamminasata area. The four regencies / cities are metropolitan areas based on Presidential Regulation 55 of 2011. Together with the issuance of the presidential regulation, the development and development of the four regions was highlighted by various parties.

Seeing the above description, performance appraisal is very important, because performance appraisal is the work of internal auditors and is a key factor for developing an organization effectively and efficiently. Good performance will be achieved if each individual does his job well, in accordance with the responsibilities and regulations or standards that apply. Variables that are the main problems in this study are organizational culture, ethical orientation, professional commitment, whistleblower and auditor performance. The object of this research is the Inspectorate in Mamminasata. Objects are taken to see how the auditor's performance in the cities and districts in South Sulawesi. On the basis of this background, this research entitled "Analysis of Auditor Performance through Professional Commitments and Whistleblowers".

\section{Literature Riview \\ Goal Setting Theory}

This study uses the Goal-Setting Theory proposed by Locke (1968) as the main theory (grand theory). Goal-Setting Theory is one form of motivation theory. Goal-Setting Theory emphasizes the importance of the relationship between the goals set and the performance produced. The basic concept is someone who is able to understand the goals expected by the organization, so that understanding will affect his work behavior. Goal-Setting Theory implies that an individual is committed to the goal (Robbins, 2008). If an individual is committed to achieving his goals, then that commitment will affect his actions and affect the consequences of his performance. Achievement of the goals (objectives) that are set can be seen as the goals / level of performance that the individual wants to achieve. Overall, intention in relation to the goals set, is a strong motivation in realizing its performance. Individuals must have the skills, have goals and receive feedback to assess their performance. Achievement of goals (objectives) has an influence on employee behavior and performance in organizations (Locke and Latham in Lunenburg, 2011).

\section{Theory of Prososial Behavior}

Prosocial behavior theory was developed by Eisenberg in 1979. This theory says that, prosocial behavior refers to actions on behalf of other people involving net costs for actors. These actions include sharing, entertaining or helping other people in trouble, and making contributions to someone in need. Prosocial moral reasoning involves reasoning about actions in which individuals must choose between satisfying their wants and needs or others, in a context where law, punishment, authority, formal obligations, and other external criteria are irrelevant or not emphasized (Eisenberg-Berg \& Hand, 1979).

Sears (1991: 47) explains that behavior is basically goal oriented in other words; our behavior is generally motivated by a desire to achieve certain goals. The specific purpose is not always known consciously by the individual. The basic unit of behavior is an activity; in fact we can state that behavior is a series of activities. Prosocial behavior is a part of daily life that includes a broader category covering all forms of actions taken that are planned for others 
without regard to the helper's motives. Prosocial behavior ranges from altruistic actions that are selfless or selfless, to helpful actions that are fully motivated by self-interest.

\section{Theory of Planned Behavior}

The theory that is widely used to understand individual behavior is known as Theory of Reasoned Action proposed by Fishbein and Ajzen (1975). Then this theory was further developed by Ajzen (1985) into the Theory of Planned Behavior (TPB) which was shown to predict individual behavior more specifically. According to Ajzen (1991) the central factor of individual behavior is that the behavior is influenced by the intention of the individual (behavior intention) towards that particular behavior. The intention to behave is influenced by three components, namely (1) attitude, (2) subjective norms and perceptions of behavioral control (perceived behavior control).

A person can have a variety of beliefs about a behavior, but when faced with a particular event, only a few of these beliefs arise to influence behavior. This little belief stands out in influencing behavior (Ajzen, 1991). This prominent belief can be divided into three, first belief behaviors, namely individual beliefs about the results of a behavior and evaluation of these results. Belief behavior will influence attitudes toward behavior (attitude toward behavior). The second is normative belief, which is the individual's belief in the normative expectations of others, which are his references such as family, friends, and tax consultants, as well as motivation to achieve those expectations. This normative expectation forms a subjective norm for a behavior. Third is control belief, namely the individual's beliefs about the existence of things that support or hinder his behavior and his perception of how strong these things affect his behavior

\section{Culture Organizations}

In social science, in general it cannot be done by measuring a construct directly, so at least two different measurements must be used. This mental program by Hofstede is explained by two constructs, namely value and culture. Value is defined as a broad tendency to show certain state of affairs over others, whose measurements use belief, attitudes, and personality. Whereas culture is defined by Hofstede (1991: 4) as a mental patterned thinking program, feeling (feeling) and action (action) or called "software of the mind". Programming starts from the family environment, then continues with the neighborhood, school, youth group, work environment, and community environment. Thus culture is a value system adopted by an environment, both family environment, school environment, work environment, to the wider community. Veithzal Rivai (2003: 40) explains that organizational culture is a value system that can be applied and developed continuously. Organizational culture also functions as an adhesive, unifying, motivator and development that is different from other organizations, which can generate encouragement to achieve and improve performance and morale.

\section{Ethic Orientation}

According to Forsyth (1980) ethical values (ethical orientation) are driven by two characteristics, namely idealism and relativism. Idealism is an ethical orientation that refers to the extent to which a person is concerned with the welfare of others and strives hard not to harm others, his opponent is pragmatism. Relativism is an ethical orientation that refers to the rejection of moral principles (rules) that are universal or absolute, the opposite is nonrelativist. Furthermore Shaub, et. al (1993) said that the two concepts of Forsyth's ethical orientation, namely idealism and relativism, were not opposites, but represented two separate scales.

Forsyth (1980) argues that idealism refers to a thing that is trusted by individuals with the consequences that they have and want not to violate moral values. Or it can be said in every action taken must be based on valid moral values and not the slightest out of these values (absolute). Idealism is defined as an attitude that assumes that the right or right action will produce the desired consequences or results.

\section{Professional Commitment}

Aranya et al (1981: 272) define professional commitment as the relative strength of individual identification with involvement in a profession and include the belief and acceptance of professional goals and values, the desire to make every effort for the organization, and the desire to maintain membership from a profession.

Commitment defined in the accounting literature Aranya et al (1981: 272) uses the definition of three branches, namely (1) A trust and acceptance of the goals and values of the organization and / or profession, (2) Willingness to put sufficient effort into the organization and / or profession, (3) Commitment is divided into two, namely professional commitment and organizational commitment (Bline et al., 1992). Bline et al. (1992) found that 
professional commitment and organizational commitment indicated two different constructs. Organizational commitment and professional commitment are distinguished empirically and predicted by different variables. For example, organizational commitment is related to the type of employee organization, while professional commitment is estimated by support for the group and positive attitudes towards the profession and job characteristics. Organizational commitment and professional commitment are different psychological experiences for professionals and that they can be explained by different individual and organizational variables.

\section{Whistleblower}

KPK (2002) describes the whistleblower as a person who reports potential acts of corruption that occur within the organization where he works, and he has access to sufficient information about the indication of corruption. An employee can report corruption cases being carried out by their seniors to the internal supervision team at the company but there is no guarantee that the whistleblower's identity will be kept confidential, but when reported to the KPK, the identity is kept confidential.

The action of a whistleblower is called a whistleblowing. There are many definitions of whistleblowing in the workplace, for example Miceli and Near (1992) define whistleblowing as reporting errors to individuals or organizations believed to have the power to stop them. GOV. UK (2015) explains whistleblowers are workers who report several types of errors. This will usually be something that is seen at work even though not always. A whistleblower is protected by law where employees may not be treated unfairly or lose their jobs as a result of disclosure of secrets in the public interest.

Lewis (2005) said that whistleblowing can be seen as part of a strategy to maintain and improve quality. From the perspective of the employer, the worker who first reports to his manager for the violations that occur can give the company the opportunity to correct the problem before developing more complicated.

\section{Auditor Performance}

According to Mangkunegara (2011: 67) the meaning of performance is a thing or result that has been achieved by an employee in a company in accordance with the authority and responsibility of each in an effort to achieve corporate objectives legally, not violating the law and not against moral or ethical.

Auditor performance according to Mardiasmo (2004: 179) is a systematic process to obtain evidence objectively, in order to be able to assess independently of the economy and efficient operations, effectiveness in achieving desired results and compliance with policies, applicable legal regulations, determine conformity between the performance achieved with predetermined criteria and communicating the results to the parties using the report.

The theory of work performance refers more to psychological theory, namely about one's work behavior process, so that someone produces something that is the purpose of his work (Agustia, 2006: 104). Performance or work performance can be measured through criteria such as quality, quantity, time taken, position held, absenteeism and safety in carrying out work duties.

Priesty and Budiartha (2017) conducted research with the aim of analyzing the influence of professional ethics and the auditor's professional commitment to auditor performance through professional skepticism at a public accounting firm in Bali. Based on the results of the analysis, the variables of professional ethics and auditor professional commitment positively influence the performance of auditors in public accounting firms in Bali.

Abdullah (2017) conducted a study on the effect of professionalism and organizational commitment on employee performance at the South Sulawesi Provincial Inspectorate office. Research found that all the hypotheses in this study were proven. 1) Professionalism and organizational commitment together have a positive and significant effect on employee performance, 2) professionalism has a positive and significant effect on employee performance, and 3) organizational commitment has a positive and significant effect on employee performance. The implication in this study is that professionalism and organizational commitment have an equally important role both individually and jointly in improving employee performance.

Andini (2017) conducts research on factors that influence auditor performance. This study aims to determine the effects of audit structure, organizational commitment, role conflict and information technology as factors that 
influence auditor performance. The results of hypothesis testing indicate that Organizational Commitment variables have an effect on and significant on auditor performance.

Janitra's (2017) research on the Effect of Ethical Orientation, Professional Commitment, Organizational Commitment, and Ethical Sensitivity against Whistleblowing concludes that ethical orientation, professional commitment, organizational commitment, and ethical sensitivity have a significant positive effect on Whistleblowing Internal.

Kurniawan, et al. (2017) conducted research with the aim of examining the effect of auditor independence, auditor integrity, auditor professionalism, professional ethics, and leadership style on auditor performance at the BPK Representative of Aceh Province. The results of the research simultaneously show that together the Auditor's Independence, Auditor Integrity, Auditor Professionalism, Professional Ethics and Leadership Style influence the performance of the BPK Representatives of Aceh Province's auditors.

Riska (2017) conducts research that aims to examine the auditor's professional influence, ethical idealism orientation, and relativism on whistleblowing with ethical sensitivity as a moderating variable. The results of the study with multiple linear regression analysis showed that professional auditors and idealistic ethical orientation had a positive effect on Whistleblowing, while the orientation of ethical relativism had a negative effect on whistleblowing. The analysis of the moderating variable with the absolute difference value approach shows that ethical sensitivity moderates the auditor's professionalism and ethical idealism toward whistleblowing orientation. But it is not able to moderate the orientation of ethical relativism towards whistleblowing.

Rossita and Sukartha (2017) conduct research on the influence of competencies, organizational commitment, professional skepticism and motivation on audit quality. The multiple linear regression analysis tests was used as an analysis technique and the results showed that the competency variable had a positive effect on audit quality, the organizational commitment variable had a positive effect on audit quality, the professional skepticism variable had a positive effect on audit quality and the motivation variable had a positive effect on audit quality.

Bouville (2016) conducted research on Whistle-blowing and morality. This study explains that the hidden fact is to blow a whistle is indeed a choice, not an objective task problem. It is also imperative that if it fails to achieve anything then blowing the whistle is the wrong decision or maybe the right decision that nobody wants to make. The Whistleblower must try to act like a saint. However, it is logically impossible to make a whistleblowing as a mandatory activity and a whistleblower as a hero or saint.

Parianti, et al. (2016) conducted a study that aimed to examine the factors that influence the whistleblowing behavior of accounting students. The results of this study indicate attitudes toward behavior, subjective norms and perceptions of control over behavior have a positive effect on the intention of accounting students to conduct whistleblowing. Likewise the perception of control over behavior and intentions has a positive effect on whistleblowing behavior.

Dayanti (2015) conducted a study that aimed to examine the effect of competencies, organizational commitment and motivation of auditors on the performance of auditors at the Semarang Audit Board (BPK). The results of this study indicate that competence, and motivation has a significant positive effect on auditor performance. While for organizational commitment does not have a positive effect on auditor performance.

Erwin and Ramsay (2015) conducted research on Whistleblowing Environment in Indonesian Financial Institutions. This study investigated the whistleblowing environment in Indonesian financial institutions from the perspective of Indonesian Company employees. The result is that in general Indonesian Financial Institutions have a positive sign of whistleblowing activities, where companies create a positive environment that supports these activities even though more can be done by the government to regulate and enforce compliance to encourage trust in protecting employees when whistleblowing.

Prasetiyani (2015) conducted research on the effects of self-control, independence, professional skills, audit training, and work experience on the performance of internal auditors. This study aims to determine the factors that can affect the performance of government auditors. The results showed that the variables of internal self-control, 
independence, professional proficiency, and audit training had a positive influence on the performance of government auditors, while the audit experience variable had no effect on the performance of government auditors.

Erkmen et. Al (2012) conducted a study of An Empirical research about whistleblowing behavior in accounting context. The purpose of this study is to analyze whether whistleblowing is a fact in professional accounting when there are serious errors in the workplace and to investigate the differences between accounting professionals and whistleblowing intentions according to demographic variables. The results obtained from this study are that internal whistleblowing is not found significantly that is determined by the state of work, total tenure, membership and number of customers.

Brennan and Kelly (2007) conducted a study on A Study of Whistleblowing among Trainee Auditors. A survey of 240 final year students from the Institute of Chartered Accountants in Ireland. Auditor trainees were asked about their confidence in the internal and external reporting structure of their company. The results show that where companies have an adequate formal structure for error reporting, trainee auditors are more likely to report errors and have greater confidence that this will not affect their careers. Training increases this trust. Auditor trainees also expressed willingness to challenge audit partners unsatisfactory responses to errors. Significant differences were found in attitude depending on whether the error report was internal or external.

Based on the correlation of theory and previous research, the hypotheses to be tested in this study are as follows. $\mathrm{H} 1$ : organizational culture influences professional commitment.

$\mathrm{H} 2$ : organizational culture influences auditor performance through professional commitment.

H3: ethical orientation influences professional commitment

H4: ethical orientation influences auditor performance through professional commitment

H5: organizational culture influences whistleblowers

H6: organizational culture influences the auditor's performance through a whistleblower.

H7: ethical orientation affects the whistleblower.

H8: ethical orientation influences the auditor's performance through a whistleblower.

H9: professional commitment influences auditor performance.

H10: whistleblowers affect auditor performance.

\section{Methodology:-}

This study uses a quantitative research approach using primary data. The object of this research is internal government auditors working at the district / city regional inspectorate. The population in this study were all Makassar City inspector auditors, Maros Regency inspectorate auditors, Gowa Regency inspector auditors and Takalar District inspectorate auditors. The research respondent is the auditor of the inspectorate who holds the position of the first auditor, the young auditor and the Official of the Local Government Affairs (P2UPD). The sample selection technique used is based on criteria (purposive sampling. The method of data collection used is the survey method using a questionnaire. Furthermore, the technique of distribution used is personally administered questionnaires.

The auditor performance variable uses the Kalbers and Fogarty (1995) instrument, organizational culture variables using the Hofstede (1990) instrument, ethical orientation variables using the instrument Forsyth (1990), professional commitment variables using the Aranya et. al (1981), and the whistleblower variable uses the instruments Brennan and Kelly (2007) and Habbe, et al. (2018). The data collected is then processed using the SmartPLS 3 data processing application.

\section{Result and Discussion:-}

The number of questionnaires distributed to respondents was 94 questionnaires. Of the numbers distributed there were 23 questionnaires that were not filled in completely and not returned so that the total questionnaires that were worthy of being used for data purposes were 76 questionnaires. The value of the outer model or the correlation between constructs and variables did not meet convergence validity at first because there are indicators that have a value of loading factors below 0.60 . Model modification is done by issuing indicators that have a value of loading factors below 0.60 . Testing shows that all loading factors have values above 0.60 so that the constructs for all variables are nonexistent eliminated from the model. The value of loading factor for each indicator of each latent variable still has the highest loading factor value compared to the loading value if associated with other latent 
variables. This means that every latent variable has good discriminant validity where some latent variables still have a measure that correlates highly with other constructs, and all constructs meet reliable criteria. This is indicated by the composite reliability value above 0.70 and AVE above 0.50 as the recommended criteria.

Testing the first hypothesis direct effect of organizational culture on professional commitment to shows the path coefficient value of $0.712 \mathrm{t}$ value obtained at 12.063 . This value is greater than table $(1,960)$. This result means that professional commitment has a significant positive effect on auditor performance. Based on these results, thus Hypothesis 1 is accepted. Testing of the influence of mediation between intervening variables and the dependent variable is done by calculating the Sobel formula. The $t$ value of 2.122 is greater than 1.96 which means that the mediation parameter is significant. So thus the model of indirect influence of organizational culture variables on auditor performance through professional commitment is acceptable. Thus Hypothesis 2 is accepted.

Testing the third hypothesis direct effect of ethical orientation on professional commitment to shows the path coefficient value of $0.312 \mathrm{t}$ value obtained at 4.667 . This value is greater than $\mathrm{t}$ table $(1,960)$. This result means that professional commitment has a significant positive effect on auditor performance. Based on these results, thus Hypothesis 3 is accepted. Testing of the influence of mediation between intervening variables and the dependent variable is done by calculating the Sobel formula. The t value of 1.961 is greater than 1.96 which means that the mediation parameter is significant. So thus the model of the indirect effect of ethical orientation variables on auditor performance through professional commitment is acceptable. Thus Hypothesis 4 is accepted.

Testing the fifth hypothesis direct effect of organizational culture on whistleblowers shows the path coefficient value of 0.720 the value of $t$ obtained at 3.729. This value is greater than table $(1,960)$. This result means that professional commitment has a significant positive effect on auditor performance. Based on these results, Thus Hypothesis 5 is accepted. Testing of the influence of mediation between intervening variables and the dependent variable is done by calculating the Sobel formula. The t value of 2.523 is greater than 1.96 which means that the mediation parameter is significant. Then the model of indirect influence of organizational culture variables on auditor performance through a whistleblower is accepted. Thus Hypothesis 6 is accepted.

Testing the seventh hypothesis the direct effect of ethical orientation on whistleblowers shows the path coefficient value of 0.002 . The value of $t$ obtained is 0.010 . This value is smaller than table $(1,960)$. This result means that the ethical orientation of the whistleblower has no significant influence. Based on these results, thus Hypothesis 7 is rejected. Testing of the influence of mediation between intervening variables and the dependent variable is done by calculating the Sobel formula. The t value of 0.009 is smaller than 1.96 which means that the mediation parameter is not significant. Then the model of the indirect effect of the ethical orientation variable on the auditor's performance through the whistleblower is not accepted. Thus Hypothesis 8 is rejected.

The $\mathrm{t}$ value of 2.159 is greater than 1.96 which means that the mediation parameter is significant. So thus the model of the direct effect of professional commitment variables on auditor performance can be accepted. Thus Hypothesis 9 is accepted. The $t$ value of 3.554 is greater than 1.96 which means that the mediation parameter is significant. So thus the model of the direct effect of the whistleblower variable on auditor performance can be accepted. Thus Hypothesis 10 is accepted.

Table 4.1:-Result for Inner Weight

\begin{tabular}{|c|c|c|c|c|c|}
\hline \multirow{2}{*}{ Variabel } & Original Sample & Mean of & Standard & \multirow{2}{*}{ T-Statistics } & P-Values \\
\cline { 2 - 5 } & Estimate & Subsamples & Deviation & & 12.063 \\
\hline CO $\rightarrow$ PC & 0.712 & 0.715 & 0.059 & 4.667 & 0.000 \\
\hline EO $\rightarrow$ PC & 0.312 & 0.282 & 0.061 & 3.729 & 0.000 \\
\hline CO $\rightarrow$ WB & 0.720 & 0.748 & 0.193 & 0.010 & 0.992 \\
\hline EO $\rightarrow$ WB & 0.002 & -0.020 & 0.216 & 2.159 & 0.031 \\
\hline PC $\rightarrow$ AP & 0.292 & 0.300 & 0.135 & 3.554 & 0.000 \\
\hline WB $\rightarrow$ AP & 0.500 & 0.502 & 0.141 & & \\
\hline
\end{tabular}




\section{Conclusion:-}

Based on the results of testing hypotheses and discussing the influence of organizational culture and ethical orientation on auditor performance by mediating professional competence and whistleblowers, conclusions can be drawn as follows:

Organizational culture influences auditor performance through professional commitment. Testing the influence of organizational culture on professional commitment is supported by the results of tests conducted by Prabayanthi and Widhiyani (2018) which show the results of analysis that the variables of professionalism, organizational culture and organizational commitment positively influence auditor performance. This shows that the higher the professionalism, organizational culture and organizational commitment possessed by an auditor, the higher the auditor's performance produced. The effect of professional commitment in ethical decision making by APIP auditors will be higher if it is supported by the higher APIP auditor organization culture. Conversely, if the support of an organizational culture is getting lower then ethical decision making will be even lower, (Mudassir, 2017). The results of the study reinforce hypothesis testing so that the influence of organizational culture clearly reinforces professional commitment

Ethical orientation influences auditor performance through professional commitment. The results of this study support the previous research, namely the research of Kurniawam et al. (2012) which shows that together Auditor Independence, Auditor Integrity, Auditor Professionalism, Professional Ethics and Leadership Style influence the performance of BPK Representatives of Aceh Province auditors, while partially that Auditor Independence, Auditor Integrity, Auditor Professionalism, Professional Ethics and Style Leadership influences performance on the performance of BPK Representatives of Aceh Province auditors. The results of this study also support the research conducted by Sari (2015) on the influence of ethical orientation and experience on the ethical sensitivity of internal auditors with professional commitment as an intervening variable. The hypothesis test conducted shows the results that ethical orientation has a positive and significant effect on professional commitment.

Organizational culture influences the auditor's performance through a whistleblower. The results of this study support the study of Yenlisa (2016) conducted in three provinces in Indonesia, namely Province D.I. Yogyakarta, DKI Jakarta and North Sumatra. The results of the study indicate that organizational culture involving culture outside the organization such as the culture that developed in the community involving ethnic groups in each province gave different results towards the intention to carry out whistleblowing actions. This greatly affects one's intention to become a whistleblower. Whistleblowers should have good performance, high education, domicile as supervisors, and higher moral reasoning than an inactive fraud supervisor (Elias, 2008). However, disclosure of violations generally results in consequences that are not desired by the disclosure of such violations, such as losing a job, threatening revenge, and isolation at work. The theory used in explaining whistleblowers is prosocial theory. Taylor (2009) reveals that prosocial behavior includes any action that is helpful or designed to help others, regardless of the helper's motives. Prosocial behavior is influenced by the type of relationship between people, for example because they like, feel an obligation, have selfishness, or empathy, someone usually helps people who are better known than unknown people. However, giving help to strangers often occurs. This theory also explains that the norms of social justice and social responsibility support a person in doing something he thinks is right. Prosocial theory is in line with the theory developed by Ajzen (1991). A person can have a variety of beliefs about a behavior, but when faced with a particular event, only a few of these beliefs arise to influence behavior. This little belief stands out in influencing behavior (Ajzen, 1991).

Ethical orientation influences the auditor's performance through a whistleblower. The results of this study contradict the research of Janitra (2017) on the Effect of Ethical Orientation, Professional Commitment, Organizational Commitment, and Ethical Sensitivity against Whistleblowing resulting in the conclusion that ethical orientation, professional commitment, organizational commitment, and ethical sensitivity had a significant positive effect on Whistleblowing Internal. The test results show the Orientation of Ethical Relativism influences the Whistleblowing Internal. High relativism tends to neglect the principle and lack of sense of responsibility in one's life experience. So that if staff / employees have high relativism, they will tend to commit unethical behavior and consider internal whiskey as an important action to avoid unethical staff / employee attitudes that can harm the organization. Whistleblowers should have good performance, high education, domicile as supervisors, and higher moral reasoning than an inactive fraud supervisor (Elias, 2008). However, disclosure of violations generally results in consequences that are not desired by the disclosure of such violations, such as losing a job, threatening revenge, and isolation at work. The theory used in explaining whistleblowers is prosocial theory. Taylor (2009) reveals that 
prosocial behavior includes any action that is helpful or designed to help others, regardless of the helper's motives. Prosocial theory is in line with the theory developed by Ajzen (1991). A person can have a variety of beliefs about behavior, but when faced with a particular event, only a few of these beliefs arise to influence behavior. This little belief stands out in influencing behavior (Ajzen, 1991). Forsyth (1980) suggests Relativism is an attitude of rejection of absolute moral values in directing behavior. In this case the individual still considers several values from within himself and the surrounding environment. Ethical relativism is a theory that states that an action can be said to be ethical or not, right or wrong, which depends on the views of society. This theory believes that each individual and group has different ethical beliefs.

Professional commitment influences auditor performance. The results of this study support the study of Priesty and Budiartha (2017) who conducted the study with the aim of analyzing the influence of professional ethics and auditor professional commitment to auditor performance through professional skepticism at the public accounting firm in Bali. Based on the results of the analysis, the variables of professional ethics and auditor professional commitment positively influence the performance of auditors in public accounting firms in Bali. The research conducted by Kurniawan et al. (2017) with the title of influence of auditor independence, auditor integrity, auditor professionalism, professional ethics and leadership style on auditor performance in the BPK Representative of Aceh Province shows the results that professional commitment has a significant positive effect on auditor performance.

Whistleblowers affect auditor performance. Similar to the research conducted by Panjaitan (2018) regarding A Study of Whistleblowing among Trainee Auditors. A survey of 240 final year students from the Institute of Chartered Accountants in Ireland. The results show that where companies have an adequate formal structure for error reporting, trainee auditors are more likely to report errors and have greater confidence that this will not affect their careers. According to this study, with the courage to become a whistleblower, the performance of an auditor is not in doubt. Research on the influence of the whistleblower on the performance of auditors stole a lot of international attention. Research in the form of articles, ideas in various electronic media often observe the influence of whistleblowing to people who want to become a whistleblower. A law firm in Washington DC, Zuckerman Law Firm, pays full attention to the action of a whistleblower. Jason

Zuckerman and Matthew Stock (2018) in his article entitled Whistleblower Protection and Incentives for Auditors and Accountants discussed the effects of the actions of auditors who were whistleblowers. According to their research and referring to the whistleblower protection provision of the Sarbanes-Oxley Act (SOX), a whistleblower will improve the performance of an auditor because it involves several things that can only be done by an auditor. This is checking financial statements. The auditor can immediately find out the irregularities that exist in the financial statements and can ask for the evidence needed to reveal the strangeness found in the report. The auditor's performance referred to here is how an auditor wants to disclose what he gets during the inspection process. Similar to the research conducted by Panjaitan (2018) entitled Whistleblowing: Improving Forensic Audit Results in Disclosing Corruption Actions by Government Auditors. The results of this study indicate that: Whistleblowing has a positive and significant effect on improving the results of Forensic Audit. These results obtained information about the need for expanded practice of whistleblowing by combining audit aspects. Thus, whistleblowing can contribute to improving the results of forensic audits. Referring to the use of questionnaires adapted from Brennan and Kelly (2007) and Habbe, et al. (2018), researchers have redesigned the questionnaire used by selecting the right construct to represent the whistleblower variable. Where statements are used, such as - I will be able to resolve a difficult ethical dilemma as above if they arise in practice, if I am forced to "blow a whistle" I am sure that the current labor law will protect me, if I forced to report concerns to external authorities, my career prospects will not suffer, if I am forced to report concerns to external authorities, my career prospects will not suffer, if I report internal problems in my organization using a formal reporting structure, career prospects I will not be disturbed. If I find a serious mistake, I will pursue this problem until it is completely corrected regardless of whether or not specific legislative protections are deemed to represent the measurement of the whistleblower variable on the auditor's performance. 


\section{References:-}

1. Abdullah. 2017. Pengaruh Profesionalisme dan Komitmen Organisasi Terhadap Kinerja Pegawai Pada Kantor Inspektorat Provinsi Sulawesi Selatan. Makassar: Fakultas Ekonomi dan Bisnis Islam Uin Alauddin Makassar.

2. Ajzen, Icek. 1985. From Intentions to Actions: A Theory of Planned Behavior. In J. Kuhl and J. Beckman (Eds.), Action Control: From Cognition to Behavior (hal. 11-39). Heidelberg: Springer.

3. Ajzen, Icek. 1991. The Theory Of Planned Behavior. Organizational Behavior and Human Decision Processes, (Online), Vol 50, 179-211, (https://www. sciencedirect.com, diakses 18 April 2018).

4. Ajzen, Icek. 2005. Attitudes, Personality and Behavior. 2nd Edition. Berkshire. UK: Open University PressMcGraw Hill Education.

5. Aranya, N., Pollock, J., dan Amernic, J. 1981. An Examination of Professional Commitment in Public Accounting. Accounting, Organizations and Society, (Online), Vol. 6, No. 4, pp. 271-280, (https://econpapers.Repec. org, diakses 18 April 2018).

6. Aranya, N., and Ferris, K. R. 1984. A Reexamintaion of Accountants' Organization Profesional Coflict. The Acounting Review, (Online), Vol. 59 No.1, (https://www.emeraldinsight.com/, diakses 18 April 2018).

7. Bline, Meixner, dan Aranya. N. 1992. "The Impact Of The Work Setting On The Organizational \& Profesional Commitment of Accountants". Research in Govermental \& Non Profit Accounting, Vol. 7, 79-96.

8. Bouville, Mathieu. 2016. Whistle-blowing and Morality. The Journal of Business Ethics, (Online), Vol. 20:43; p.1 (http://www.springerlink.com diakses tanggal 10 Mei 2018)

9. Brennan, Niamh., Kelly, John. 2007. A Study of Whistleblowing among Trainee Auditors. British Accounting Review, (Online), Vol. 39(1), 61-87), (https://papers.ssrn.com diakses tanggal 16 Mei 2018)

10. Dayaksini, Tri dan Hudaniah. 2003. Psikologi Sosial. Malang: UMM.

11. Detik.News. 2011. (https://news.detik.com/berita/1718598/diduga-terima-suap-walikota-tomohon-dua-auditorbpk-ditahan-kpk, diakses tanggal 10 Mei 2018).

12. Eisenberg-Berg, N., \& Hand, M. 1979. The relationship of preschoolers' reasoning about prosocial moral con• icts to prosocial behavior. Child Development, (Online), Vol. 50, No. 2 (Jun., 1979), pp. 356-363, (http://www.jstor.org, diakses 28 Mei 2018).

13. Eisenhardt, Kathleen M. 1989. Agency Theory: An Assessment and Review. The Academy of Management Review, (Online), Vol. 14, No. 1, (https://www.jstor.org, diakses 20 April 2018)

14. Erkmen, Turhan., Caliskan, Arzu Ozsozgun., Esen, Emel. 2012. An empirical research about whistleblowing behavior in accounting context. Journal of Accounting \& Organizational Change, (Online), Vol. 10 No. 2, pp. 229-243 (www.emeraldinsight.com, diakses tanggal 10 Mei 2018)

15. Erwin, Jennifer., Ramsay, Associate Professor Dr. Barry. 2015. Whistleblowing Environment in Indonesian Financial Institutions. International Journal of Business and Social Research, (Online), Volume 05, Issue 11, (https://thejournalofbusiness.org, diakses tanggal 15 Mei 2018).

16. Febrianty. 2012. Pengaruh Profesionalisme Auditor Terhadap Pertimbangan Tingkat Matrealitas Audit Atas Laporan Keuangan. Jurnal Ekonomi dan Informasi Akuntasi. 2(2): h: 159-200

17. Forsyth, D. R. 1980. “A Taxonomy of Ethical Ideology”. Journal of Personality and Social Psicology, Vol. 39, 175-184.

18. Foster, Bill. 2001. Pembinaan Untuk Peningkatan Kinerja Karyawan. Jakarta: PPM.

19. Ghozali, Imam. 2015. Partial Least Square, Konsep, Teknik Dan Aplikasi menggunakan Program SmartPLS 3.0. Edisi 2. Semarang: Undip.

20. Goldwasser. 1993. "The Plaintiffs' Bar Discusses Auditor Performance." Journal of CPA, (Online), (http://archives.cpajournal.com, diakses 20 Mei 2018).

21. Habbe, Abdul Hamid., Rasyid, Syarifuddin., Arif, Hermita. 2018. Measuring Internal Auditor's Intention To Blow The Whistle (A Quasi-Experiment Of Internal Auditors In The Local Government). Faculty of Economic and Business, University of Hasanuddin, Makassar, Indonesia. (Working Paper)

22. Hasibuan, Sp. Melayu. 2010. Manajemen Sumber Daya Manusia. Jakarta: Bumi Aksara

23. Hofstede, G., Bram Neuijen, Denise Daval Ohayv, and Geert Sanders. 1990. Measuring Organizational Culture.: A Quantitative and Qualitative Study Across Twenty Cases. Administrative Science Quarterly, (Online), 35: 286-316 (https://www.researchgate.net, diakses 30 April 2018).

24. Hoffman, W. Michael and Robert E. 2008. “A Business Ethics Theory of Whistleblowing”. Journal of Business and Environmental Ethics. Bentley University, Waltham MA. USA, (Online) 45-59 (https://www.bentley.edu/, diakses 30 April 2018).

25. Hwang, D., Staley, B., Chen, Y. T., and Lan, J. S., 2008. Confucian Culture and Whistleblowing by Professional Accountants: An Exploratory Study. Managerial Auditing Journal, 23(5), pp. 504-526. 
26. Imawan, Muhammad Riswanda. 2017. Internal Auditor dengan Praktik Whistleblowing, (http://jtanzilco.com/blog/detail/699/slug/internal-auditor-dengan-praktik-whistleblowing, diakses 30 Mei 2018)

27. Inspektorat Daerah Kabupaten/Kota Makassar. 2018. (http://www.inspektorat.makassarkota.go.id/strukturorganisasi, diakses 10 Mei 2018).

28. Inspektorat Daerah Kabupaten/Kota Maros. 2018 (http://inspektorat.maroskab.go.id/index.php/profilinspektorat, diakses 10 Mei 2018).

29. Inspektorat Daerah Kabupaten/Kota Takalar. 2018. (http://www.takalarkab.go.id/index.php/profil-inspektorat, (diakses tanggal 10 Mei 2018)

30. Irawati, Anik. 2012. Pengaruh Orientasi Etika Pada Komitmen Profesional, Komitmen Organisasi dan Sensitivitas Etika dengan gender sebagai Variabel Pemoderasi. Tesis. Yogyakarta: Program Magister Akuntansi Fakultas Ekonomika Dan Bisnis Universitas Gadjah Mada

31. Janitra, Wimpi Abhirama. 2017. Pengaruh Orientasi Etika, Komitmen Profesional, Komitmen Organisasi, Dan Sensitivitas Etis Terhadap Internal Whistleblowing. JOM Fekon, (Online), Vol. 4 No. 1, (https://jom.unri.ac.id, diakses 30 April 2018)

32. Jaros, Stephen. 2007. Meyer and Allen Model of Organizational Commitment: Measurement Issues. The Icfai Journal of Organizational Behavior, (Online), Vol. 6, No 4, 2007. Hal 7-25, (https://pdfs. semanticscholar.org, diakses 30 April 2018).

33. Jensen, Michael C., Meckling, William H. 1976. Theory of the Firm: Managerial Behavior, Agency Costs and Ownership Structure. Journal of Financial Economics, (Online), Vol. 3, No. 4, pp. 305-360, (https://www.sciencedirect.com, diakses 20 April 2018).

34. Kalbers, L. and P.T. Fogarty. "Professionalism and Its Consequences: A Study of Internal Auditors." Journal of Auditing 14, no. 1 (Sarasota: Spring 1995):64.

35. Keputusan Ketua LAN Nomor 239/IX/6/8/2003, tanggal 25 Maret 2003, tentang Perbaikan Penyusunan Pelaporan Akuntabilitas Kinerja Instansi Pemerintah.

36. Khairul, Dzakirin. 2011. Orientasi Idealisme, Relativisme, Tingkat Pengetahuan, dan Gender: Pengaruhnya pada Persepsi Mahasiswa tentang Krisis Etika Akuntan Profesional. Skripsi. Malang: Fakultas Ekonomi dan Bisnis Universitas Brawijaya.

37. Khomsiyah dan Indriantoro Nur. 1998. Pengaruh Orientasi Etika Terhadap Komitmen dan Sensitivitas Etika Auditor Pemerintah di DKI Jakarta. Jurnal Riset Akuntansi Indonesia. Vol. I, No. 1, Januari: 13-28.

38. KPK. 2002. KPK Whistleblower System. (https://kws.kpk.go.id diakses 21 Mei 2018)

39. Kurniawan, Dwi Sumartono Agung., Nadirsyah., Syukriy Abdullah. 2017. pengaruh independensi auditor, integritas auditor, profesionalisme auditor, etika profesi, dan gaya kepemimpinan terhadap kinerja auditor di BPK Perwakilan Provinsi Aceh. Jurnal Magister Akuntansi Pascasarjana Universitas Syiah Kuala, (Online), Vol. 6 No. 3 (www.jurnal.unsyiah.ac.id diakses tanggal 10 Mei 2018).

40. Kusuma, Andi., Syamsuddin., Sundari, Sri. 2017. External Auditor Profesional Skeptics in Producing Audit Quality. International Journal of Economic Research, (Online) Vol. 14, No. 2.

41. Larkin, Joseph M. 1990. Does gender Affect Auditor KAPs' Performance?, The Woman CPA. Spring pp. 20-24

42. Larkin Joseph M. 2000. The Ability of Internal Auditors to Identify Ethical Dilemmas. Journal of Bisiness Ethics, (Online) Vol. 23, pp. 401-409, (https://link.springer.com, diakses tanggal 10 Mei 2018).

43. Lekatompessy, J.E. 2003. Hubungan profesonalisme dengan konsekuensinya: komitmen organisasional, kepuasan kerja, prestasi kerja, keinginan berpindah (Studi Empiris di lingkungan Akuntan Publik). Jurnal Bisnis dan akuntansi. Vol.5 No.1 Hlm.69-84.

44. Lewis, David. 2005. "The Contents of Whistleblowing/Confidential Reporting Procedures in The UK". Employee Relations. Vol. 28, No. 1, 76-86

45. Locke, E.A., dan Latham. 1990. A Theory of Goal Setting and Task Performance. New Jersey: Prentice-Hall Inc.

46. Lunenburg, Fred C. 2011. Goal-Setting Theory of Motivation. International Journal Of Management, Business, And Administration, (Online) Vol.15, No. 1, (http://www.nationalforum.com, diakses 20 Juni 2018).

47. Mangkunegara, Anwar Prabu. 2005. Sumber Daya Manusia Perusahaan. Bandung: Remaja Rosda karya.

48. Mangkunegara, Anwar Prabu. 2011. "Evaluasi Kinerja", Cetakan Pertama, Bandung: PT.Refika Aditama.

49. Mardiasmo. 2004. Akuntansi Sektor Publik. Yogyakarta: Andi Publisher.

50. Martin, J. 1992. Cultures in organizations; three perspectives. New York: Oxford University Press.

51. Meyer J and Allen N (1997), “Commitment in the Workplace: Theory, Research, and Application”. Sage Publications.

52. Miceli, M. P., and Near, J., (1992). Blowing the Whistle: The Organizational and Legal Implications for Companies and Employees. New Jersey: Lexington Books. 
53. Mowday, R., Porter, L. and Steers, R. 1992. Employee-Organization Linkages: The Psychology of Commitment, Absenteeism, and Turnover. New York: Academic Press.

54. Mulyadi, Aditya Wisnu. 2015. Perlindungan Hukum terhadap Whistleblower dan Justice Collaborator dalam Tindak Pidana Korupsi. Tesis. Denpasar: Program Pascasarjana Universitas udayana.

55. Pemerintah Daerah Kabupaten Gowa. 2018. (http://gowakab.go.id/skpd/ dinas/inspektorat-daerah, (diakses tanggal 20 Mei 2018).

56. Pemerintah Provinsi Sulawesi Selatan. 2018. (https://sulselprov.go.id/upload/ files/RENSTRA\%2020131018_REV.pdf, diakses tanggal 30 April 2018).

57. Peraturan Menteri Dalam Negeri Nomor 64 Tahun 2007 tentang Pedoman Teknis Organisasi dan Tata Kerja Inspektorat Provinsi dan Kabupaten/Kota.

58. Peraturan Menteri Negara Pendayagunaan Aparatur Negara Nomor : PER/05/M.PAN/03/2008. Tentang Standar Audit Aparat Pengawasan: Intern Pemerintah.

59. Peraturan Pemerintah Republik Indonesis Nomor 41 Tahun 2007 Tentang Organisasi Perangkat Daerah.

60. Riska. 2017. Pengaruh Profesional Auditor, Orientasi Etika Idealisme, dan Relativisme Terhadap Whistleblowing dengan Sensitivitas Etis sebagai Variabel Moderating. Makassar: Fakultas Ekonomi dan Bisnis Islam Uin Alauddin Makassar.

61. Robbins, Stephen P. dan Timothy A. 2008. Judge. Perilaku Organisasi Edisi 12. Jakarta: Salemba Empat.

62. Ross, Stephen A. 1973. The Economic Theory of Agency: The Principals Problem. American Economic Association, Vol 6 No. 2

63. Rossita, Ni Made Dian., Sukartha, I Made. 2017. Pengaruh Kompetensi, Komitmen Organisasi, Skeptisme Profesional dan Motivasi Pada Kualitas Audit. E-Jurnal Akuntansi Universitas Udayana, (Online), Vol. 20.3, (https://ojs.unud.ac.id, diakses tanggal 20 Mei 2018)

64. Sears, David O. 1991. Psikologi Sosial, jilid II. Jakarta : Erlangga.

65. Sekaran, Uma. \& Bougie, Roger. 2016. Reaserch Methods for Business. A Skill-building Approach. Seventh Edition. Wiley.

66. Shaub, Michael K., and Don W. Finn. 1993. The Effect of Auditor's Ethical Orientation on Commitment and Ethical Sensitivity. Behavioral Research in Accounting. Vol. Five, 146-166

67. Siegel, G. \& Helene, R.M. 1989. Behavioral Accounting. Ohio: South-Western Publishing Co. Cincinnati.

68. Singgih, E. M., \& Icuk, R. B. 2010. Pengaruh Independensi, Pengalaman, Due Professional Care dan Akuntabilitas Terhadap Kualitas Audit. Simposium Nasional Akuntansi.

69. Steers, M Richard. 1985. Efektivitas Organisasi Perusahaan. Jakarta: Erlangga.

70. TEMPO/Aditya Herlambang Putra. 2010. (https://nasional.tempo.co/read/269116/ kpk-gelar-rekonstruki-kasussuap-pejabat-bpk-di-bandung, diakses tanggal 10 Mei 2018).

71. Transparancy.org. 2018 (http://www.transparancy.org/country/IDN\#, diakses tanggal 12 April 2018)

72. Undang-undang No.14 tahun 2008 dari Kementerian Dalam Negeri Republik Indonesia

73. Van, Dyne, L dan Graham J.W. 2005. Organizational Citizenship Behavior; Construct Redefinition Measurement and Validation. Academiy Management Journal, (Online), 37 (4) pp 765-802, (soonang.com, diakses 20 April 2018).

74. Veithzhal, Rivai. 2003. Kepemimpinan Dan Perilaku Organisasi. Jakarta: PT. Rajagrafindo Persada.

75. Whistleblowing for employees.2018. (https://www.gov.uk/whistleblowing, (diakses tanggal 20 April 2018).

76. Zuckerman, Jason., dan Stock, Matthew. 2018. Whistleblower Protections and Incentives for Auditors and Accountants, (Online), (https://www.zuckermanlaw.com/whistleblower-protections-and-incentives-for-auditorsand-accountants/, diakses 30 Oktober 2018). 